\title{
UNIVERSITY HOSPITAL OF THE FEDERAL UNIVERSITY OF SANTA CATARINA: THE KNOWLEDGE-POWER OF NURSE TEACHERS (1975-1980) ${ }^{1}$
}

\author{
Juliana Bonetti de Carvalho², Miriam Süsskind Borenstein ${ }^{3}$, Ana Rosete Maia4, Jaime Alonso Caravaca- \\ Morera $^{5}$
}

\footnotetext{
${ }^{1}$ Extract from the thesis - University Hospital of the Federal University of Santa Catarina: the power of nurses in the organization and implementation of the Nursing Service (1975 - 1990), presented in the Programa de Pós-Graduação em Enfermagem (PEN) at Universidade Federal de Santa Catarina (UFSC) in 2013.

2 Doctoral Student at PEN/UFSC. Florianópolis, Santa Catarina, Brazil. Email: julianapersempre@hotmail.com

${ }^{3}$ Ph.D. in Nursing. Professor at PEN/UFSC. Florianópolis, Santa Catarina, Brazil. Email: miriam@nfr.ufsc.br

${ }^{4}$ Ph.D. in Nursing. Professor at the Departamento de Enfermagem of UFSC. Florianópolis, Santa Catarina, Brazil. Email: anamaia8@ hotmail.com

${ }^{5}$ Doctoral Student at PEN/UFSC. Nurse at Universidad de Costa Rica. San José, Costa Rica. Email: jacamorera@hotmail.com
}

\begin{abstract}
The objective of this study was to historicize the creation of the University Hospital of the Federal University of Santa Catarina and the power of nurse teachers in the organization of the nursing department of this hospital, based on their knowledge. It is a qualitative study and a socio-historical approach that utilizes oral thematic history and documentary analysis. Interviews were conducted with five nurse teachers and a doctor. Data were categorized utilizing thematic context analysis based on the Foucaultian framework. Results demonstrate that the process of construction of the hospital and the organization of the nursing were permeated with struggles and resistance. Nurse teachers exercised the power, ensuring many achievements due to their knowledge. It was concluded that, from the knowledge developed by nurse teachers, the proper professional attitude, and a willingness to provide quality care, the nursing department conquered its space and organized a nursing care systematized in the hospital, which served as a model for several health care institutions.
\end{abstract}

DESCRIPTORS: Nursing. History of nursing. University hospitals. Hospital nursing service.

\section{HOSPITAL UNIVERSITÁRIO DA UNIVERSIDADE FEDERAL DE SANTA CATARINA: O SABER-PODER DAS ENFERMEIRAS DOCENTES (1975-1980)}

RESUMO: O objetivo foi historicizar a criação do Hospital Universitário da Universidade Federal de Santa Catarina e o poder das enfermeiras docentes na organização da enfermagem deste hospital, a partir de seus saberes. Estudo qualitativo, abordagem sócio-histórica que utiliza história oral temática e análise documental. Foram realizadas entrevistas com cinco enfermeiras docentes e um médico. Os dados foram categorizados utilizando-se análise de conteúdo temática, com base no referencial foucaultiano. Os resultados demonstraram que o processo de construção do hospital e a organização da enfermagem foram permeados por lutas e resistências. As enfermeiras docentes exerceram o poder, garantindo conquistas, em virtude de seus saberes. Conclui-se que, a partir do saber constituído pelas enfermeiras docentes, da adequada postura profissional e da vontade de prestar uma assistência de qualidade, a enfermagem conquistou seu espaço e organizou um Serviço de Enfermagem sistematizado no referido hospital, que serviu de modelo para inúmeras instituições de saúde. DESCRITORES: Enfermagem. História da enfermagem. Hospitais universitários. Serviço hospitalar de enfermagem.

\section{HOSPITAL UNIVERSITARIO DE LA UNIVERSIDAD FEDERAL DE SANTA CATARINA: EL SABER-PODER DE LAS ENFERMERAS DOCENTES (1975-1980)}

RESUMEN: Investigación cualitativa, socio-histórica que objetivó historizar la creación del Hospital Universitario de la Universidad Federal de Santa Catarina y el poder de las enfermeras docentes en la organización de la enfermería en este hospital. Se utilizó historia oral temática y análisis documental. Se realizaron entrevistas con cinco enfermeras docentes y un médico. Los datos fueron categorizados utilizando análisis de contenido temático basado en el marco teórico de Foucault. Los resultados demuestran que el proceso de construcción del Hospital y organización de enfermería estuvieron permeados de muchas luchas y resistencias. Enfermeros docentes ejercían el poder, asegurando muchos logros, en virtud de sus conocimientos. Se concluye que a partir de conocimientos constituidos por las enfermeras docentes, la actitud profesional adecuada y la voluntad de ofrecer asistencia de calidad, la enfermería conquistó su espacio y organizó un Servicio de Enfermería sistematizado, que sirvió como un modelo para diversas instituciones de salud.

DESCRIPTORES: Enfermería. Historia de la enfermería. Hospitales universitarios. Servicio de enfermería del hospital. 


\section{INTRODUCTION}

University hospitals (UH) were created in order to provide technical support for the development of knowledge acquired in the theoretical classes held in the medical schools of Brazil. According to the researched literature, on November $7^{\text {th }} 1922$ the São Francisco de Assis Teaching Hospital (formerly the São Francisco de Assis Nursing Home) was opened in Rio de Janeiro under the responsibility of the National Public Health Department (DNSP). ${ }^{1}$ This hospital marked the beginning of the creation of university hospitals in Brazil. The Clinics Hospital of São Paulo may be mentioned as well. In 1923, the state government and the Rockefeller Foundation launched negotiations for the planning and execution of the work, but the hospital was not opened until 1944 . $^{2}$

These and other university hospitals gained recognition during the 1940s and 1950s as specific health services of universities. Previously, such educational activities were developed in charitable organizations that made their facilities and clientele available. ${ }^{3}$

During the government of President Juscelino Kubitschek de Oliveira (1956-1961), Brazil experienced a real and remarkable economic growth with its accelerated industrialization process. During that period, there was a strengthening of the economy of urban centers that generated a workforce to be served by the health system. As a result, the state took up the responsibility for the health of the workers, maintaining and restoring their productive capacity. Individualized medical care became prevalent, and the political climate motivated the privatization of services and promoted the development of hospital activities. ${ }^{4}$ During the 1960s and 1970s there was a rapid expansion of university hospitals and a growth in the number of medical schools, characterized as the backbone of high-complexity health systems, or specialized tertiary care, of the country. ${ }^{3}$

In Florianópolis, particularly from the decade of 1960, the base of the economy began to change due to the Economic Development Plan - a target plan of the government of Juscelino Kubitschek. Several institutions were created, including the Universidade Federal de Santa Catarina (UFSC). With the creation of this university (Law 3849 of December 18 ${ }^{\text {th }}, 1960$ ) and its aggregation with the medical school that had existed in Florianópolis since 1957, the construction of a hospital became necessary. This hospital would meet the demand of students for courses in the areas of health in their practical activities (pharmacy, dentistry, and medicine). ${ }^{5}$

The idealization of the construction of the UH/UFSC was discussed in 1963 by the professors working in the medical school, but the achievement of this dream and the opening of the aforementioned hospital only occurred in May 1980. Between the beginning and the completion of the work there were several delays that generated conflicts and protests on the part of students, health professionals, and civil society in relation to the policy of the federal government during the dictatorship period. ${ }^{6}$

In turn, the nurse teachers of the Nursing Department of UFSC became visible after the creation of the nursing school in 1969 through Resolution $02 / 69$ of January $24^{\text {th }} 1969 .{ }^{7}$ Their insertion into the decision-making processes of the planning and construction of the UH/UFSC occurred through Ordinance 418/75 of Rector Roberto Mundell de Lacerda. He appointed a multidisciplinary committee to undertake the ideal of building the aforementioned hospital. ${ }^{8}$

The planning, organization, and implementation of the nursing service in the UH/UFSC were very complex and required from the nursing team that worked on the implementation committee of the University Hospital of Santa Catarina (CIHUSC) an intensive and immediate amount of work based on a commitment to quality care. ${ }^{9}$ Considering the contribution given by the nurse teachers of the Nursing Department of UFSC to nursing at UH/UFSC, the present paper aims to historicize the process of creation of the UH/UFSC and the power of nurse teachers in the process of organization of the nursing service of that hospital based on their knowledge (1975-1980).

As an historical time marker, we have the initial period in 1975 with the insertion and participation of nurse teachers into the decision-making processes of planning and construction of the $\mathrm{UH} /$ UFSC, ending in 1980 with the completion of the respective hospital and organization of nursing.

The relevance of the present study is precisely in unveiling the wealth of detail provided by the testimonies of nurse teachers who took part in the history of the nursing service organization at the UH/UFSC combined with the historiographical void of that period in relation to the knowledge-power of the aforementioned nurses. It is also based on the importance of the $\mathrm{UH} /$ 
UFSC throughout its existence and its history of more than three decades (1980-2014) as a locus of construction and change of knowledge through professional training, care development, teaching, and research.

\section{METHODOLOGY}

This is a qualitative research study with a socio-historical approach using thematic oral history. The researcher is required to have a special interest in knowing and understanding a past event in order to conduct historical research. The historical investigation aims at "shedding light on the past so that it may brighten the present and even evidence some future issues" ${ }^{10: 577}$

Data were collected by means of the oral history method using semi-structured interviews that were conducted between January and March 2012. Oral history is a "historical, anthropological and sociological research method that focuses on interviews", ${ }^{11: 18}$ and that generates sources of information for further studies. In addition to the interviews, other documentary sources were used: newspapers, newsletters, ordinances, minutes, reports, laws, photos, and basic documents. These served as substantiation for the present research, allowing a contextualized analysis and interpretation of the data.

An active search for the telephone numbers in the Nursing Department Secretariat of UFSC and UH/UFSC was conducted in order to locate the individuals to be interviewed. Initially, a telephone contact was made, and subsequently an appropriate day and place were scheduled for each interviewee. The interviews were conducted in places defined by the individuals of the study (UFSC, current workplace, or their home) and took an average of 90 minutes each. The questions were guided by a previously elaborated script containing information about the creation of the UH/UFSC, questions related to professional qualification, power in the process of organization of the nursing service of the UH-UFSC, and the achievements brought about by the construction of documents that consolidated such organization. The interviews were recorded, transcribed, and then validated.

The selected individuals consisted of five nurse teachers (Rosita Saupe, Lidvina Horr, Jorge Lorenzetti, Lorena Machado e Silva, and Márcia Cruz Gerges) who were directors of nursing at the UH/UFSC and a physician (Nelson Grisard) who was the General Director of the UH/UFSC between 1981 and 1984, contributing significantly to the construction of the foundations of nursing in the respective hospital. These individuals were identified throughout the study by their respective surnames.

The first individuals were selected from an interview with Professor Rosita Saupe, first Director of Nursing of the UH/UFSC, with an understanding that such interviews should be the point of origin of the study, that is, the Ground Zero. During the interviews, the interviewees were indicated as people who had prominent roles in the organization and implementation process of the nursing service of the UH/UFSC.

Thematic content analysis ${ }^{12}$ was used. This allows the content of the interviews to be organized and integrated in the selected categories based on the aims and targets previously established and enables its interpretation from the perspective of the theory guiding the study. The analysis and interpretation of the data were conducted in light of the theoretical framework of Michel Foucault by bringing the need to establish a dialogue with the contemporary philosophical and historical foundations and thinking about past events with a view to illuminating present history. ${ }^{13}$

The research project complied with the guidelines and requirements of Resolution $466 / 12$ of the National Health Council and was analyzed and approved by the Human Research Ethics Committee of the Pro-Rectory for Research and Extension of the Federal University of Santa Catarina under the number 2420/11-FR 483711. The individuals participating in the research were instructed in relation to: the type of research; their choice to participate or not; the confidentiality of some of the information; the use of photographic images, videos, and recordings of reports; as well as the possibility to interrupt the interview and ask for clarifications; and being able to withdraw at any stage of the process. Upon clarification and acceptance by the individuals, the Informed Consent form and the Letter of Assignment of the interview were signed by them.

\section{RESULTS AND DISCUSSION}

Two categories were found in the data analysis: The beginning of the University Hospital of Santa Catarina - a history of struggles and resistance; and the knowledge-power of nurse teachers: achievements for the space of nursing. 
The beginning of the University Hospital of Santa Catarina - a history of struggle and resistance

The dream of building a teaching hospital in Florianópolis was initially conceived in the late 1950s by the professors of the medical school. They verified this need after observing that the hospitals in that region were unable to offer an appropriate structure to maintain or raise the standard of excellence in teaching health sciences. With the creation of UFSC in December 1960 and the incorporation of the medical school (Law 3849) ${ }^{14}$ that dream became possible. ${ }^{15}$

The idealization of the project had Professor Polydoro Ernani de São Thiago ${ }^{6}$ as its main mentor. In relation to the definition of the name, several designations were suggested over time; the definitive name came in the decade of 1990, as described below:

[...] initially, the UH was called Clinical Hospital of the University of Santa Catarina, then UH of the Federal University of Santa Catarina. After the passing of its founder, Professor Polydoro, we, in conjunction with the University Council, decided to name the hospital University Hospital Professor Polydoro Ernani de São Thiago (Grisard).

The proposal was to build a teaching hospital based on ethical and scientific principles that could be an environment for the development of research, extension, and teaching activities. From 1964 the Rectory of UFSC was motivated by the almost unanimous idea of professors and students of medicine about the construction of the clinical hospital of UFSC. The work began in 1964 and was temporarily interrupted 1971. Resumed in 1976, it was finally concluded in $1980 .{ }^{16}$ This building process was very slow and went through several stages, from the start to total abandonment, as explained by Professor Jorge Lorenzetti:

[...] at that time, the late 1960s and early 1970s, there was a structure of the university hospital; the works were interrupted for years, the project was kind of abandoned (Lorenzetti).

This period between 1960 and 1970 was marked by protests and student struggles around the social and political issues related to the military dictatorship. Despite the full support of Rector João David Ferreira Lima (according to Professor Polydoro in his book Promoting Health and Teaching: University Hospital of Santa Catarina) and the engagement of the professors, the students were considered to be the determining agents of this achievement, ${ }^{16}$ as indicated by the words below:

[...] I entered the University as a student in 1971 and soon I started to participate in the student movement. In 1972 I was elected President of the Student Union of the whole area of Health, as at that time there were no Student Unions for each course; it was the Student Union of the Biomedical Center, involving Medicine, Dentistry, Nursing, Pharmacy [...]. In addition to the general political ideals of fighting the dictatorship and for the democratization of the country, the Union decided to prioritize protests through a public campaign for the completion of the University Hospital. We conducted a campaign with state and national impact, student demonstrations, distribution of open letters to the population, bumper stickers: "University Hospital is a need of students and people" (Lorenzetti).

[...] by the time I graduated the Brazilian politics were boiling. We were always involved with social movements. The country was transitioning from a dictatorship to democracy, it was going through this process. We, young people, liked to go into battles, to search for references; we had ideals. At that time we participated in marches, we wanted to be involved, fighting for better conditions of life. Since our student time we participated in ABEN-SC, we knew our rights and duties as nurses (Gerges).

The keynote of the testimonies of the nurse teachers expresses the importance of the strategies of struggle and resistance performed by the student movement against military authoritarianism and for democratic freedom. We understand that the strategies of resistance and struggle should attempt to present the same characteristics as power, that is: they should be inventive; mobile; productive; organized; and consolidated with this as it is constituted ${ }^{17}$.

These students defended their political ideals with enthusiasm and determination, fighting the dictatorship with the support of civil society, the public institutions of Santa Catarina, and the press. The flag of the struggle for quality health led them to Brasília in order to have a meeting with the Minister of Education at that moment General Jarbas Passarinho - and find a solution for the much-criticized "ghost with stakes," the Clinical Hospital.

[...] we went to Brasilia, we had a meeting with the Minister of Education at the time, Jarbas Passarinho, who was a strongman of the dictatorship. He was a military [man], but he was very receptive. He blamed UFSC for not having a completion project of the hospital filed in the Ministry. Then we returned and declared publicly that it was the university's fault, as the Min- 
ister had explained that there was no project in Brasilia requesting the completion of the university hospital. People of the city were very critical about that; there was a significant local media attention (Lorenzetti).

As a result of this answer brought by the students, "the Rectory decides to set up a commission to study the case of the Clinical Hospital". ${ }^{18: 8}$ Under the headline "Students Campaigning in Favor of Hospital Are Supported by Commission," the newspaper $O$ Estado interviewed the President of the Commission, Professor Polydoro de São Thiago, who congratulated the student movement. ${ }^{19}$ "On December $11^{\text {th }} 1975$, the Rector Roberto Mündell de Lacerda announced the resumption of the works of the construction of the Hospital; it was opened during the administration of the Rector Caspar Erich Stemmer (1976-1980) with the name University Hospital" ${ }^{20: 52}$

It may be observed that the struggle for the completion of the building works of the UH/UFSC did not follow a linear and consensual course on the part of all of the people involved and interested in such building. For the physicians and the Rectory, the struggle was for the construction of a therapeutic space for clinical education. Also, there was an interest in maintaining the hegemony of the medical power. The student movement defended a speech respecting the right of the population to have access to quality health care and democratic freedom. This found resonance in civil society (the population, the press, the church, and others), which intensified the movement of struggle and resistance to power of that period.

This rhetoric of struggle and resistance permeated the entire social body and the population based on the perspective of understanding the power in its positivity. According to Foucault, this means much more than a simple negative force: "what makes power to be maintained and accepted is the simple fact that it weights not only as a force saying no, but also permeating, producing things, inducing pleasure, forming knowledge, producing speech". 17:8

\section{The knowledge-power of nurse teachers: achievements for the space of nursing}

As previously mentioned, the nurse teachers who participated in the process of organization of the nursing service of the UH/UFSC came from the graduate program in nursing created in 1969 as a result of the motivation of members of the Brazilian Association of Nursing of Santa Catarina (ABEn-
SC). Professor Eloíta Pereira Neves, President of ABEn-SC in that period, along with the other associated nurses, drew up a petition justifying the need to create the course in order to promote the full development of nursing in Santa Catarina. ${ }^{21}$

By the year 1949, there were already 15 nursing schools in Brazil; most of them were concentrated in the Southeastern region. This number rose to 39 schools by 1964 . These data reflect a favorable time for the creation of one more school in the Southern region, with multiple possibilities. ${ }^{22-23}$

Recognition for the nursing course occurred through Decree 76,853 of December 17 1975 issued by President (at the time) Ernesto Geisel. The course was created in a very specific moment of Brazilian education, when the reform of universities was under study and about to be concretized at UFSC. ${ }^{6}$

From the university reform created in 1968, implemented by Law $5540 / 68$ of November $28^{\text {th }}$ 1968 , and entered into force in 1970, changes in Brazilian higher education were instituted. ${ }^{24}$ This restructuring process generated several changes, with related courses being divided into departments, as shown by the statement below:

[...] at that time there was no nursing department; there was the nursing course. Then, after the university reform, this departments system was created (Saupe).

With the university reform, nursing was detached from the medical school and gained autonomy to execute its activities as well as more space to discuss issues related to the profession, thus treading its own path. The first nurses to integrate the faculty of the Nursing Department were selected and hired by UFSC at the request of Professor Eloita Pereira Neves, coordinator of the course at the time. Professor Neves aimed to form a high-level team, committed and engaged with the purposes of the course, and qualified to perform the activities pertinent to the profession. Professor Rosita Saupe, first Director of Nursing of the UH/ UFSC recalls her admission to the department:

A group of classmates, Eloita Pereira Neves and Irmgard Bruckheimer Roza, were from Santa Catarina, and at the time they accepted the invitation to open the Children's Hospital Edith Gama Ramos [...]. A few years later Eloita was invited to organize the nursing course at the university. She contacted me and invited me to participate in the first group of professors (Saupe).

It is worth emphasizing that the selection of the faculty was directly connected with the theo- 
retical and practical experience of each nurse. All of them presented very rich past experiences, thus allowing the construction of a qualified, organized, and independent nursing staff. This reality may be best viewed through the testimonies of the nurses:

I had a great professional experience in maternity, emergency, medical clinics and surgical clinics [...]. I participated in the first group that opened the FEMINA hospital in Porto Alegre [...]. In Porto Alegre I was head of Infirmary; I have always presented a certain natural leadership characteristic (Saupe).

[...] before graduating in nursing I was a primary education teacher. I taught in a school for 12 years and I was the principal in a school in Rio Fortuna [...]. I had already worked at the Hospital Servidores (Horr).

From the Foucauldian perspective, nurse teachers had a discursive practice consolidated by the knowledge acquired in their daily practice and based on the theoretical and practical experiences gained in the university system, ${ }^{17}$ in this sense, they constituted a knowledge of nursing.

The everyday life of the Nursing Department occurred with the effective participation of the nurse teachers who worked in both the teaching and the administrative areas. Research was not part of the tradition of nursing, as postgraduate courses only began to be created in the decade of 1970. "During the first years of the Nursing Course of UFSC teaching was the major concern of the professors. [...] the professors gradually advanced in the construction and consolidation of a quality teaching". 25:119

Professor Eloita Pereira Neves was aware that the training and qualification of the faculty were required to ensure this quality teaching. Therefore, in the beginning of the hiring process, professors were referred to other education and health care institutions in order to increase their knowledge in the discipline that they would teach and in their future administrative positions. Professor Lorena Machado e Silva depicts this reality in her testimony:

[...] I had an extensive curriculum at the time. [...] I opted for midwifery nursing and then I began to study several areas when I entered the Department. I studied higher education methodology in Porto Alegre, focused on administrative areas, and several other courses (Silva).

The work of the nurse faculty at the UH/ UFSC meant much more than a simple place for the practice of patient care; it meant a space for the establishment of knowledge-power. According to
Foucault, power is not something to be obtained or an object to be possessed; it is something exercised and disputed. And it is not a univocal, unilateral relationship; this dispute is won or lost. ${ }^{17: x v}$ Despite the Foucauldian perspective in institutions and particularly in health institutions, it is necessary to ensure the space through organization charts.

As a result, there was a need to fight for a space on the organization chart that allowed for higher autonomy in decision making, and the construction of documents to substantiate a care practice in the UH/UFSC that would result in quality teaching and care. An organization chart is a "graphic representation of the structure of the organization/company or service that lists the positions and hierarchical authorities" .26:58 The words of the nurse teacher Rosita Saupe evidences the desire and determination to implement an exemplary nursing service:

[...] for most doctors, education was only an extension so that they could have the title of professor. But we did not think that way. We were exclusively dedicated and believed that our future was there [at UH/UFSC]. We were very focused on making a hospital in the way we thought it, operating with a powerful nursing. Quality would come as a result of the model that we wanted to implement (Saupe).

From the social perspective and the point of view of the professionals, the physicians held the hegemonic power in health institutions. For them, work in the educational area was simply characterized as a matter of social status. On the other hand, nurse teachers were proud to work in this area and were very committed to the profession. The UH/UFSC meant the creation of a high-level teaching space for the students and consequently a quality nursing service to the population. They wanted a nursing service with autonomy and decision-making power; it should be differentiated and able to change the practice and strengthen the profession. At the time there was little appreciation of either the professionals or the care itself. The professionals performed their duties in a slightly politicized and even somewhat disorganized way. That, as a reality, was something that the nurse teachers of UFSC wanted to change. ${ }^{27}$

The constant presence of nurse teachers in meetings and debates about the UH/UFSC allowed the attainment of spaces desired by nursing. The nurse teachers formulated the clauses of the Nursing Department and sent them to the Special Commission of the University Hospital of UFSC. 
The document included everything from their philosophical beliefs to the claim for a position of authority in the organization chart. ${ }^{25}$ The interviewed nurse teachers considered the position reached in the institutional chart - occupying the same level as other boards - to be one of the first and major achievements of nursing in relation to the work in the UH/UFSC. This was due to an achievement through knowledge that was implemented, and with this, the respective power.

A study conducted in 2005 in the University Hospital of Bahia showed that placing the position of nursing in the organization chart at the same level as medical and management boards allowed a higher level of autonomy in decisionmaking processes. This fact is not common in the Brazilian hospital reality; usually the nursing service is subordinate to the medical service ${ }^{28}$. The words of the interviewees demonstrate that this achievement made a difference to nursing in the UH and in UFSC:

[...] the most striking aspect of the work of nursing in the Implementation Committee of the UH was the decision about the organizational structure of the hospital [...]. We assumed that from the scientific and management perspective it was unacceptable and inadmissible that nursing was not at the top level of the structure [...]. Nursing had already achieved some space and a higher level of autonomy (Lorenzetti).

[...] the organization charts have always been at the center of our struggles. [...] In the old organization chart nursing was subordinated to the medical services. I talked with Dr. Polydoro. Gladly, he said: 'Oh, Professor, after all of our discussions, here is our organization chart.' I saw it and replied: 'Professor, we shall have a differentiated responsibility here. We will need nurses in all the units, because it is a teaching hospital. We have to show the nursing administration model that we adopted.' He said: 'Do you want nursing at the same level as the medical board?' I answered: 'Yes, this is what we want; we believe we deserve it. We have performed a work here and we want to show to the people and users of Santa Catarina that we will honor our position; and you will have great conditions of work with this nursing.' And so we were successful! (Saupe).

[...] when the university hospital was about to open I said to Doctor Stemmer: 'We cannot open it without a nursing board!' Because they wanted to open the administration board and another one that I cannot remember now. I said to Doctor Stemmer: 'The highest number of employees in the university hospital will consist of nursing staff; so it is necessary to have a structure, someone to command it.' [...] then the University, upon approval of the bylaw, opened a space that gave us the same power as the others through the nursing board (Horr).

The testimonies evidence that nursing successfully achieved a position of power in the UH/UFSC, not at the bottom of the organization chart, but participating on the board. This is what happened; based on the presented knowledge, nursing remained as part of the board. All of the successes of the nurse teachers and their participation in the nursing planning and organization, the therapeutic space, and the systematization of care were legitimized as a result of their knowledge and their constant search for knowledge and qualification, as well as through the power established by the institution, to occupy leadership positions at all levels.

These struggles of nurses to ensure space and positions in the organization chart as well as articulations to make the organization of nursing and care viable in the UH/UFSC are in accordance with the philosophical thought of Foucault. The author discusses the relations of power in the organizational space. He acknowledges the strength that is embedded in the relations of power and how it behaves to produce effects, proposing a perspective of positivity, productivity, and subjectivity. ${ }^{17}$

\section{FINAL CONSIDERATIONS}

The present study enabled us to understand the reality experienced by nurse teachers at UFSC within the complicated political moment of the military dictatorship and with intense social movements, claims, struggles, and resistance.

The words of the nurse teachers express the desire to implement an organized and systematized nursing based on ethical and scientific principles at the UH/UFSC that could be a model for the nursing services of Santa Catarina. The aforementioned nurses were able to fight for their knowledge-power through professional experiences of teaching, management, and qualification courses they had previously attended. Thus, based on the Foucauldian perspective, the history of these nurses showed that their power resulted from a continuous and diffuse struggle that has spread throughout the construction process of the $\mathrm{UH} / \mathrm{UFSC}$ in the new knowledge-power relations.

This is verified based on the engaged participation of nurse teachers in the meetings of the implementation committee, the knowledge 
brought and the knowledge constituted by them, their professional behavior, and the confidence arising from a differentiated nursing. Thus, the profession gained recognition in the UH/UFSC. Initially this nursing department had a subordinate position in relation to the general board, but through genuine struggle it managed to establish the organization of a systematized nursing service at the UH/UFSC and served as a model for a series of state and federal health institutions, generating a greater visibility for the nurses and the nursing service of UFSC.

This study shows the beginning of a history that still needs to be unveiled, a history of great challenges and achievements generated by the work of a small group of young, idealistic nurse teachers with a transformative vision. Their presence in the space of UH/UFSC showed the clinics as a field of knowledge, practice, experience, and disciplined space for knowledge-power and power-knowledge beyond nursing, aiming at the construction of a multidisciplinary knowledge.

\section{REFERENCES}

1. Ministério da Educação (BR). Universidade Federal do Rio de Janeiro: Hospital Escola São Francisco de Assis. [acesso 2015 Fev 22]. Disponível em: http:// portal.mec.gov.br/sesu/arquivos/pdf/hefranc.pdf

2. Hospital de Clínicas da Universidade de São Paulo. [página da Internet]. São Paulo, 2015. [acesso 2015 Fev 22]. Disponível em: http:// www.hc.fm.usp.br/index.php?option $=\mathrm{com}_{-}$ content\&view $=$ article\&id $=485 \&$ Itemid $=303$

3. Caldas Junior AL. A crise nos hospitais universitários: estratégia de privatização. Univ Soc. Brasília. 1999 Set-Dez; 9(20):133-8.

4. Paulus Junior A, Cordoni Junior L. Políticas públicas de saúde no Brasil. Rev Espaço para Saúde. 2006 Dez; 8(1):13-9.

5. Rodrigues I. A UFSC na década de 1960: outras histórias. In: Neckel R, Kuchler ADC. UFSC 50 anos: trajetórias e desafios. Florianópolis (SC): UFSC; 2010. p.17-35.

6. Bristot LS. O Centro de Ciências da Saúde e suas histórias. In: Neckel R, Kuchler ADC. UFSC 50 anos: trajetórias e desafios. Florianópolis (SC): UFSC; 2010. p.171-89.

7. Universidade Federal de Santa Catarina. Secretaria Geral. Divisão de Pessoal. Boletim do Pessoal. 1969 Jan-Dez; 3(25):1-2.

8. Gerges MC. Integração docente assistencial ou... entre o Departamento de Enfermagem e o Hospital Universitário da Universidade Federal de Santa Catarina. Texto Contexto Enferm. 1995; 4(esp):230-7.
9. Horr L, Rabello ES, Sakae SV, Cipriano ZM. Em busca de um sonho. Texto Contexto Enferm. 1995; 4(esp):210-5.

10. Padilha MICS, Borenstein MS. O método de pesquisa histórica na enfermagem. Texto Contexto Enferm. 2005 Out-Dez; 14(4):575-84.

11. Alberti V. História oral: a experiência do CPDOC. Rio de Janeiro (RJ): Fundação Getúlio Vargas; 2007.

12. Minayo MCS. O desafio do conhecimento: pesquisa qualitativa em saúde. São Paulo (SP): Hucitec; 2012.

13. Foucault M. Arqueologia do saber. Rio de Janeiro (RJ): Forense Universitária; 2012.

14. Brasil. Lei n 3.849, de 18 de dezembro de 1960. Federaliza a Universidade do Rio Grande do Norte, cria a Universidade de Santa Catarina e dá outras providências. Diário Oficial da União, 21 dez 1960.

15. Neckel R, Kuchler ADC. Universidade Federal de Santa Catarina-UFSC 50 anos: trajetórias e desafios. Florianópolis (SC): UFSC; 2010.

16. São Thiago PE. Promovendo saúde \& ensino: Hospital Universitário de Santa Catarina. Florianópolis (SC): UFSC; 1983.

17. Foucault M. Microfísica do poder. Rio de Janeiro (RJ): Edições Graal; 2014.

18. Acadêmicos de medicina fazem seu plebiscito pelo hospital escola. O Estado. Florianópolis (SC); 20 Mai 1973. p. 8.

19. Estudantes fazem campanha em favor de hospital e comissão dá apoio. O Estado. Florianópolis (SC); 24 Mai 1973. p.8.

20. Santos KSS. A UFSC sob o regime militar: do Centro de Estudos Básicos aos movimentos estudantis. In: Neckel R, Kuchler ADC. UFSC 50 anos: trajetórias e desafios. Florianópolis (SC): UFSC; 2010. p.36-60.

21. Borenstein MS, Althoff CR. Projetando e conquistando um caminho para a formação profissional do enfermeiro. In: Borenstein MS, Althoff CR, Souza ML. Enfermagem da UFSC: recortes de caminhos construídos e memórias (1969-1999). Florianópolis (SC): Insular; 1999. p.25-64.

22. Carlos DJD, Padilha MI, Villarinho MV, Borenstein MS, Maia ARCR. Escolas de enfermeiras no nordeste brasileiro (1943-1975). Rev Rene. 2014 Mar-Abr: 15(2):326-33.

23. Teixeira E, Vale EG, Fernandes JD, Sordi, MRL. Enfermagem. In: Haddad AE, organizador. A trajetória dos cursos de graduação na área da saúde: 1991-2004. Brasília: INEP; 2006. p.142-68.

24. Brasil. Lei n. 5.540, de 28 de novembro de 1968. Fixa normas de organização e funcionamento do ensino superior e sua articulação com a escola média e dá outras providências. Diário Oficial da União, 29 Nov 1968.

25. Bub LIR, Mendes NTC. Os primeiros 10 anos (1969-1979). In: Borenstein MS, Althoff CR, Souza ML. Enfermagem da UFSC: recortes de caminhos 
construídos e memórias (1969-1999). Florianópolis (SC): Insular; 1999. p.65-126.

26. Bauli JD, Matsuda LM. Diagnóstico situacional do serviço de enfermagem de hospital de ensino sob a ótica dos profissionais de nível médio. Rev Adm. Saúde. 2009 Abr-Jun: 11(43):55-62.

27. Albuquerque GL. A luta pela identidade profissional: participação e enfermagem [tese]. Florianópolis (SC): Universidade Federal de Santa Catarina, Programa de Pós-Graduação em Enfermagem; 2002.

28. Perrucho M, Bulcão TN, Luedy A, Tahara ATS. Análise crítica do Serviço de Enfermagem de um Hospital Universitário. Rev Baiana Enferm. 2005; 19-20(1-2-3):53-62. 